\title{
Do Inflation, Exchange Rate, Interest Rates, Tourist Visits, Government Spending and Investment Affect Indonesia's Economic Growth?
}

\author{
*Dede Wahidin ${ }^{1}$,Widia Khairunnisa ${ }^{2}$, Retna Ayu Wulandari ${ }^{3}$
}

\author{
${ }^{1}$ Nusa Putra University, Sukabumi, Indonesia \\ ${ }^{2}$ Nusa Putra University, Sukabumi, Indonesia \\ ${ }^{3}$ Nusa Putra University, Sukabumi, Indonesia \\ *Corresponding author. E-mail: dede.wahidin_ak18@nusaputra.ac.id
}

\begin{abstract}
This research is entitled "Does Inflation, Exchange Rate, Interest Rates, Tourist Visits, Government Expenditures, and Investment Affect Indonesia's Economic Growth?" intending to make the research material for evaluating the performance of tourism development and the national economy to make a significant contribution to the national economy. The presentation of data on inflation, exchange rates, interest rates, tourist visits, government spending, investment, and economic growth uses data that BPS has calculated. This method uses a quantitative approach. In this study, the data used is time-series data, namely annual data, starting in 2010-2020. Based on research results. The processing results carried out using software EVIEWS show that inflation affected Indonesia's economic growth from 2010-2020. The exchange rate influenced Indonesia's economic growth in 2010-2020; it can be seen from the partial test or t-test. Interest rates do not affect Indonesia's economic growth in 2010-2020. Tourist visits affect Indonesia's economic growth. Government spending influences Indonesia's economic growth. Investment influences Indonesia's economic growth.
\end{abstract}

Keywords: Inflation, Exchange Rates, Interest Rates, Tourist Visits, Government Expenditures, Investment and Economic Growth.

\section{INTRODUCTION}

Economic growth is a crucial metric for determining a country's level of success. Each country aims for maximum economic growth to advance as a nation. The gross domestic product, both at current and constant prices, is one of the most significant indices for determining financial circumstances over time.

Indonesia's economic growth in 2019 was 5.02 percent, much below the government's 5.2 percent objective. In reality, 2019 was the slowest year for economic growth in the previous four years. The slowing of Indonesia's economic development is inextricably linked to causes such as the US-China trade war, the United Kingdom's withdrawal from the European Union (Brexit), and a slew of events in Hong Kong, Iran, and Iraq that threaten national economic stability. In addition to these concerns, the COVID-19 epidemic, which has rocked the global economy, including Indonesia's, has hindered various key financial earning sectors, including tourism.
The government continues to prioritize the tourist industry since it is seen as having the potential to drive the nation's economic growth. After palm oil (CPO) and coal exports, tourism has become one of the third significant providers to national foreign exchange. The government is still working on improving tourist management. The government has implemented several initiatives to make Indonesian tourism more advanced and well-known across the world. A well-managed tourist business may help to brand a country, enhance foreign exchange profits, and attract other industries.

This sector has a high degree of economic interconnectedness and is capable of contributing significantly to the national economy. As a result, research on the performance of tourist development and its influence on the national economy is required. The attainment of the tourist sector's critical objectives in the national economy and the individual welfare of employees and business units involved in tourism are examined in this impact study. 
The country's tourism-related foreign exchange profits have also dropped significantly. According to the Republika.co.id website, the expected foreign exchange revenues from tourism in 2020 are between US $\$ 47$ billion, according to Minister of Tourism and Creative Industries Sandiaga Uno. Compared to the previous year, tourism foreign exchange revenues were approximately $\$ 20$ billion; therefore, this decrease is considerable. Before the epidemic, tourism earnings were expected to reach $\$ 1.921$ trillion in 2020

According to official information collected from the Indonesian Statistics Agency in 2020, the number of international tourist arrivals was 4,052 923. Malaysia, Singapore, and China are nations that commonly visit Indonesia. On the other hand, foreign visitor visits declined in 2020, owing to the pandemic that struck the tourism industry in numerous countries, including Indonesia. In December 2020, international visitors visiting Indonesia increased by 13.6 percent (MtM). The number of tourists visiting Indonesia declined by 75.0 percent in 2019 compared to the previous year, with most visitors being business tourists carrying out specific activities or missions. Tourism contributes to regional, national, and international economic growth and destination competitiveness from a macroeconomic perspective [1].

Increase. The quantity of foreign tourism exchange measures the impact of visitors on the economy. In 2020, the Indonesian rupiah exchange rate was expected to be 80 percent, or IDR 51.2 trillion. The exchange rate has a mutually useful causal link with tourism growth and economic growth, including foreign exchange for visitors and the number of tourists; the consequence of rising tourism foreign exchange is the rupiah exchange rate.

Foreign tourists will shift from countries with high exchange rates to countries with low exchange rates based on the value of the rupiah, especially the exchange rate and currency of origin of the tourist to tourist destinations. As a result, the exchange rate is one of the determining factors for foreign tourists. Essentially, the exchange rate impacts the international monetary system's structure and has significant consequences for where the global surplus will be concentrated [2].

State expenditure aims to attain national development goals such as infrastructure, reducing poverty and unemployment, and expanding connectivity in the framework of equitable development. However, in 2020, the government will focus state investment on health, social safety nets, and economic stimulation to preserve the economy and people from the COVID-19 pandemic.
In terms of government spending, inflation changed in 2020. Compared to the previous year, the inflation rate in 2020 was the lowest in the recent ten years. The inflation objectives for 2019-2021, according to Minister of Finance Regulation No. 124/PMK.010/2017, are 3.5 percent, 3.0 percent, and 3.0 percent, respectively, with a 1 percent deviation. The inflation goal is intended to guide businesses and the general public in carrying out future economic activities to keep inflation at a low and stable level. According to [3,] the inflation rate is the percentage rise in the entire price index from one year to the next. Inflation's influence may be amplified, and it can be both good and bad.

Interest rates and inflation have an inverse relationship, with interest rates falling as inflation rises. In the other case, if interest rates decrease or remain low, demand for loans increases, as consumers prefer to borrow rather than save. The more money we spend, the faster the economy grows, and inflation rises [4]. according to Lower and more stable interest rates provide greater economic certainty, encouraging many investors to borrow and invest in productivityboosting initiatives. A high GDP growth rate can have a favorable impact on a country since it enables investors to invest in the country [5].

Based on the context above, the researcher identified an issue that served as the basis for a study. As a result of the problems above, the title of this study is "Does Inflation, Exchange Rates, Interest Rates, Tourist Visits, Government Expenditures, and Investments Affect Indonesia's Economic Growth?"

\section{LITERATURE REVIEW}

\subsection{Definition Of Inflation}

Inflation is one of the macroeconomic indicators closely related to people's purchasing power. According to [6], inflation is the general and persistent tendency for prices to attract. If the price of products and services increases, the currency's value decreases. This will impact the ability to meet daily needs, especially for essential commodities. Therefore, the government needs to stabilize the prices of necessities to maintain people's purchasing power. Keeping purchasing power can encourage economic growth so that it has an impact on improving people's welfare.

\subsubsection{Determining The Inflation Rate}

The inflation rate describes the price changes that apply from one period to another. To determine it, you need to consider the consumer price index data for a certain period compared to the price index of the previous period. The formula for determining the inflation rate is as follows: 


$$
I n=\frac{I H K n-I H K n-1}{I H K-n 1} \times 100 \%
$$

\section{Description}

In : Inflation

IHKn : Consumer price index base year

IHKn-1 : Consumer price index of the previous year

\subsubsection{Inflation Developments in Indonesia}

The annual inflation rate, which is 2 percent, is also the lowest in the last ten years. It was recorded that in 2013 the amount of inflation was 8.38 percent. Furthermore, Indonesia has also experienced inflation in the range of 2 percent, in 2016, at 3.02 percent.

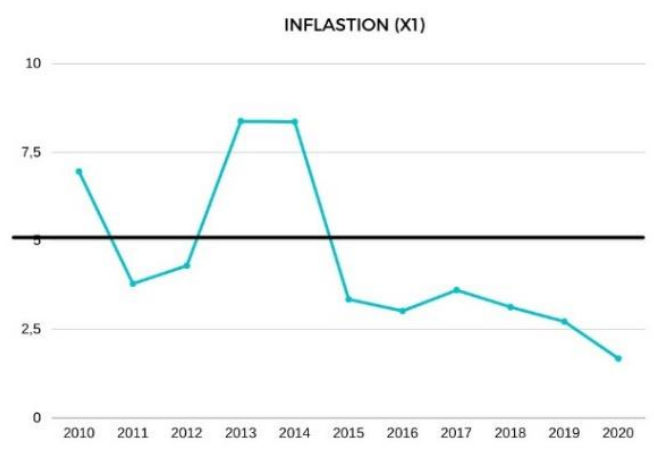

Figure 1. Indonesia's 2010-2020 Annual Inflation Rate.

In 2019, the inflation rate, in general, was recorded at 2.72 percent. The inflation rate decreased by 0.41 percent compared to 2018 (yoy), where the inflation rate was recorded at 3.13 percent. When viewed by the expenditure group, most of the expenditure groups experienced an increase in the inflation rate on a yoy basis. Only two groups shared a slowdown in the inflation rate in 2019 , namely the housing, water, electricity, gas \& fuel groups and the transportation, communication, and financial services groups.

\subsection{Exchange rate}

The exchange rate is when inhabitants of two nations agree to trade with one another. There are two sorts of negotiated exchange rates: nominal and real. The improvement in Indonesia's balance of payments aided the rupiah's strengthening. The rupiah exchange rate climbed by 0.93 percent (ptp) in December 2019 compared to November 2019, bringing the year-todate rise to 2.90 percent (ytd). The continuing supply of foreign exchange from exporters and foreign capital in keeping with Indonesia's well-maintained economic outlook, particularly appealing to uncertainties in local and global financial markets backed by massive inflows, has contributed to strengthening the Rapier. Bank Indonesia expects the rupiah currency rate will remain steady in the future, as long as fundamentals and market processes are maintained. The outlook for Indonesia's balance of payments, which is expected to remain favorable due to continued foreign capital inflows, in line with the improving domestic economic outlook and attractive yields and the positive impact of loose monetary policy in developed countries, supports this prospect is to strengthen the effect.

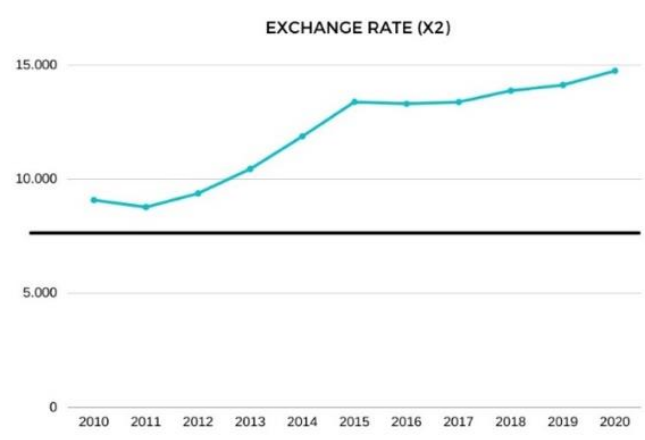

Figure 2. Indonesian exchange rate chart for 20102020.

Bank Indonesia continues to deepen financial markets, including money and foreign currency markets, through its exchange rate policy and boosting domestic finance. Due to global uncertainty and the seasonal trend of increased demand for foreign cash, the Rupiah exchange rate declined in May 2019. Following a period of rising in April 2019, the rupiah currency rate decreased by 1.45 percent point-to-point on May 15, 2019, compared to the end of April 2019 level of 1.36 percent. The effect of global mood connected to the intensification of the trade war on developing-nation currencies, especially the rupiah, was inextricably linked to the decreasing rupiah exchange rate in May 2019. In addition, the rupiah's depreciation was aided by the seasonal trend of rising demand for foreign currency for non-resident dividend payments.

\subsection{Interest Rate}

The interest rate, often known as the BI rate, is a monetary policy set by Bank Indonesia and made public. Since August 2016, Bank Indonesia has tightened the monetary operating framework by introducing the BI 7-Day (Reverse) Repo Rate as a new benchmark interest rate or policy interest rate to replace the BI rate. The BI 7-Day (Reverse) Repo 
Rate, or new policy interest rate, is utilized because it is thought to have the ability to immediately effect the money market, banking, and real sector.

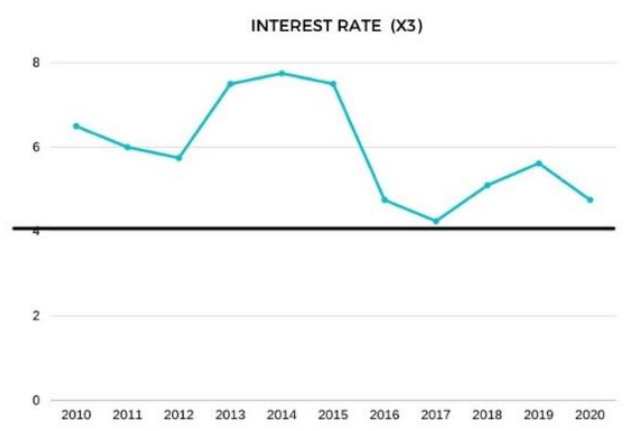

Figure 3. Indonesian interest rates during 2010-2020.

Bank Indonesia decided in early 2019 to keep the BI 7-day Reverse Repo Rate (BI7DRR) at 6.00 percent. This approach is consistent with attempts to maintain a manageable current account deficit and the attractiveness of domestic financial assets. Bank Indonesia has also maintained a monetary operation plan https://www.bps.go.id 7 Monetary Sector 132 Indonesia Economic Report 2020 to provide appropriate liquidity in both the Rupiah and foreign exchange markets, hence promoting monetary and financial system stability.

\subsection{Tourism}

Tourist has been identified as a potential economic sector contributor based on the experience of several nations that have benefited from the tourism industry [7]. The tourism sector's progress may be tracked by several metrics, including foreign exchange revenues and the number of international visitors to Indonesia. Both of these indicate an upward tendency. In 2015, 10.23 million international visitors visited Indonesia, which climbed to 16.11 million in 2019.

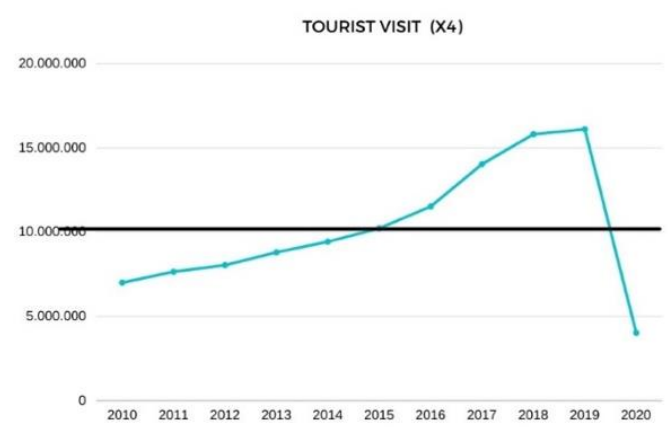

Figure 4. Indonesian tourist visits during 2010-2020.
Entering the end of 2019, the world was shaken by the spread of a new virus from China to various countries. Since the spread of the virus named Covid19 , which has now become a pandemic, in addition to impacting the economic sector of countries in the world, the tourism sector has also become one of the sectors directly affected by the impact.

\subsection{Government Expenditure}

Tourism is already recognized as a potential economic sector contributor based on the experience of several nations that have benefited their national economies through tourism [7]. The tourism sector's progress may be tracked by many metrics, including foreign exchange revenues and the number of international visitors to Indonesia. Both of these indicate an upward tendency. In 2015, 10.23 million international visitors visited Indonesia, while the figure grew to 16.11 million in 2019 ..

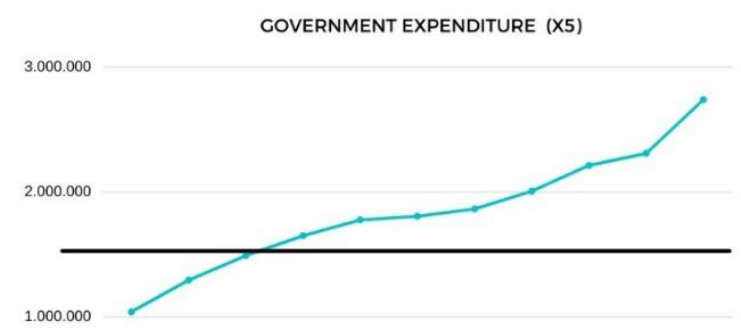

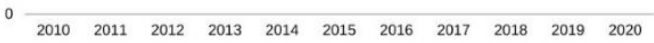

Figure 5. Indonesian government spending data for 2010-2020.

The administration is continuing its efforts to minimize the impact of Covid-19. However, the epidemic altered the course of people's lives and the country's financial system. The effect on state finances is seen in increased government spending and a corresponding drop in state income. Numerous measures and support have been implemented in response to the tremendous economic impact of Covid-19.

\subsection{Investment}

Investment is a person's willingness to allocate money or other valuable resources at present and hold them from consuming the cash until a specific time to earn a profit in the future. 


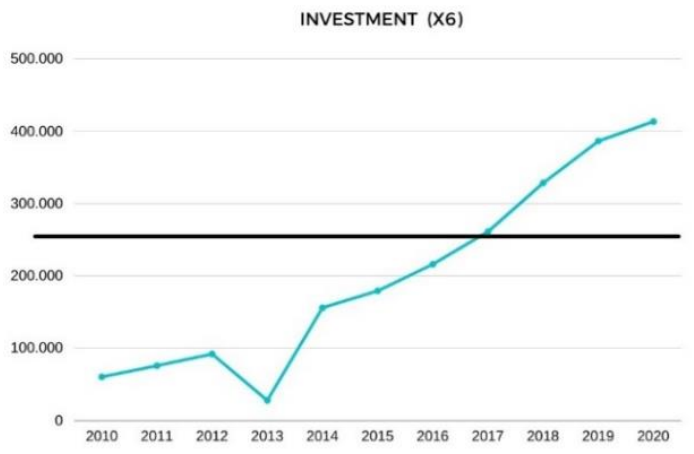

Figure 6. Indonesian government investment data for 2010-2020.

The investment realization target from the Investment Coordinating Board (BKPM) in 2020 from Domestic Investment (PMDN) and Foreign Investment (PMA) is IDR 886 trillion. Despite being in a state of cancer pandemic Covid-19, investment activities are expected to drive the community's economy.

During the 2017-2019 period, the realization of domestic investment was always recorded to increase. Investments realized throughout 2018 reached IDR 328.60 trillion, an increase of 25.25 percent compared to 2017 , which only reached IDR 262.35 trillion. An increase also followed the increase in the value of domestic investment in the number of projects that absorbed the investment value; the number of projects absorbed increased from 8,838 projects in 2017 to 10,815 projects in 2018 .

\subsection{Economic Growth}

Indonesia's economic condition is very stable amidst slowing world financial performance. In 2019, Indonesia's economic growth was able to grow to 5.02 percent, or slower than economic growth in 2018, which had reached 5.17 percent. With the global financial situation, which tends to decline in 2019, this figure is already good enough for Indonesia's economic growth. Overall, the Indonesian economy shows an improving performance with a more robust structure.

\subsection{Previous Research}

Similar research was conducted by [8] under the title "Institutions and the impact of government spending on growth," based on a study on public and private investment encouraging economic growth in developing countries with effective governance and the influence of investment. A subsequent study was undertaken by [9] under the title "Tourism and economic growth: Comparing Malaysia and Singapore," based on the previous research findings indicating tourism had a positive correlation with economic growth. Additionally, [3] researched the "Dynamic Inflation and Economic Growth Nexus in Bangladesh," and the findings indicate that inflation affects economic growth. In general, it looks as though governmental investment is more than private investment.

\subsection{Framework of Thought}

The conceptual framework is the researcher's path of thought related to the theoretical study until the variables are included in the investigation, which occurs concurrently with the conceptual framework.

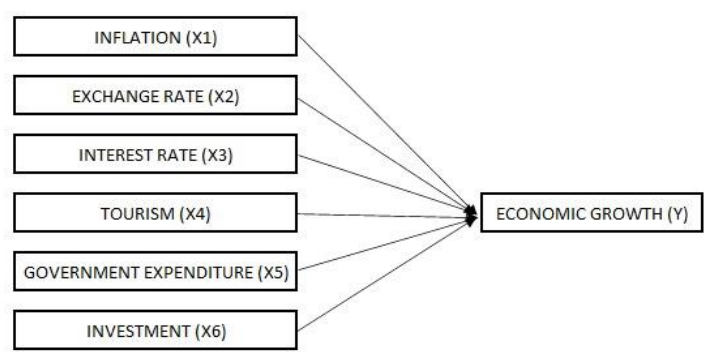

Figure 7. framework of the researcher's thinking.

\section{METHODOLOGY}

\subsection{Types of Research}

The author used a quantitative technique in this investigation. The data utilized in this study are time series data, specifically annual data from 2010 to 2020 . The inflation, currency rates, interest rates, tourist visits, government expenditure, investment, and economic growth indicators are presented using BPScalculated data. The progression of economic growth is based on data from the BPS's annual report on the Indonesian economy.

\subsection{Population}

According to [10], a research population is a collection of generic objects or individuals. Meanwhile, according to [10], a population is a collection of objects or subjects that the researcher has assigned specific values and characteristics to be studied and conclusions are drawn." Using these experts' arguments, the authors estimated the population for this study, including inflation, currency rates, interest rates, tourist visits, government expenditure, investment, and economic growth from 2010 to 2020 .

\subsection{Sample}

According to [10], a sample is a subset of the population based on its size and features. It is a sample 
deemed representative of the people since it contains the same people.

\subsection{Data Source}

This research relied on secondary sources of information. Secondary information is a source of research data received indirectly via intermediate media, i.e., data gathered and recorded by other parties. The process attempted was to acquire data from the Indonesian Central Statistics Agency's website, particularly https://www.bps.go.id. Inflation statistics, interest rate exchange rates, tourist trips abroad, government expenditure, investment, and economic development are all gathered for 2010-2020.

\subsection{Data Collection}

Techniques for data collecting can come from a variety various sources and in a variety of methods [10]. The researchers gathered data from the Indonesian economy's annual report, which can be accessed at https://www.bps.go.id.

\subsection{Tabulation of Research}

Tabulation of research data was carried out by transferring research data from Microsoft Excel to the Eviews software version 10, with six independent variables and one dependent variable.

\subsubsection{Classic Assumption Test}

A classical assumption test is a condition that must be carried out on every simple linear test. In this study, regression analysis uses the reviews ten applications because the researchers' data is timeseries data.

\subsubsection{Multicollinearity Test}

The multicollinearity test determines if there is a solid or complete connection between the independent (independent) variables in the regression model. If the correlation between the independent variables is strong, this research may exhibit multicollinearity.

\subsubsection{Normality Test}

The normality test determines whether or not the residual value follows a normal distribution. If a variable is not distributed, then the statistical test results will decrease. According to [11], The normality test on the data can be seen using the EVIEWS 10 application:

1) If the Jarque probability is greater than or equal to 0.05 , the data are regularly distributed.
2) If Jarque's probability is less than 0.05 , the data are not normally distributed.

\subsubsection{Heteroscedasticity Test}

According to [12], heteroscedasticity is used to test for variations in variance between the residuals of two observations. Heteroscedasticity refers to the variance difference between the residuals for each statement in the regression model. The regression model must satisfy specific prerequisites, including the lack of heteroscedasticity symptoms.

\subsubsection{Autocorrelation Test}

The autocorrelation test determines whether there is a connection between the residuals of one observation and those of another statement in a regression model. The Durbin-Watson Test (D-W Test) may detect if a regression model has serial correlation or whether the model contains autocorrelation between the observed variables.

\subsubsection{Model Feasibility Test (Goodness of Fit)}

The model feasibility test, often known as the $\mathrm{R}^{2}$ test, verifies an independent variable's capacity to explain the dependent variable. The range of values for $\mathrm{R}^{2}$ ranges from 0 to 99 , and the closer the $\mathrm{R}$ Square value is to 1 , the more practical the model is.

\subsubsection{Partial Test ( $t$ Test)}

The partial test (t-test) determines if the independent variable affects the dependent variable. It is performed by comparing the value of the t-value to the value of the t-table. The t-test test criteria are:

1) If the value of t-value $>t$-table, the hypothesis is rejected. That is, the variable affects the dependent variable.

2) The value of t-value \& lt; then the hypothesis is accepted. H. The variable does not affect the dependent variable.

\subsubsection{Test Simultaneous (F-Test)}

$\mathrm{T}$ The simultaneous test ( $\mathrm{F}$ test) determines if all independent variables affect the dependent variable concurrently by comparing the F-value to the F-table.

1) If the F-value is greater than the F-table, the hypothesis is rejected. This indicates that the independent factors affect the dependent variable in concert.

2) If F-value \& lt; equals F-table, the hypothesis is accepted. This indicates that grouping independent factors has no bearing on the dependent variable. 


\subsubsection{Multiple Linear Regression Analysis}

Multiple linear regression is a kind of linear regression that includes one dependent variable (Y) and six independent variables $(\mathrm{X})$.

$\mathrm{Y}_{1}=\beta 0+\beta 1 \mathrm{Xi}+\beta 1 \mathrm{X} 2+\beta 1 \mathrm{X3}+\beta 1 \mathrm{X} 4+\beta 1 \mathrm{X} 5+$

\author{
$\beta 1 \mathrm{X6}+\mu \mathrm{I}$

Description:

Y: Economic Growth

$\beta 0+\beta 1:$ Parameters

$\mathrm{X} 1$ : Inflation

X2: Exchange Rate

X3: Interest Rate

X4: Tourist Visit
X5: Government Expenditure

X6: Investment

$\mu \mathrm{i}:$ error $\mathrm{t}$

\section{RESULTS AND DISCUSSION}

\subsection{Multicollinearity Test}

The multicollinearity test is used to determine if the regression model's independent variables are highly or completely correlated (independent). If the correlation coefficients between the six independent variables are high, the study may exhibit signs of multicollinearity.

Table 1. Multicollinearity Test Results with EVIEWS 10.

\begin{tabular}{|c|c|c|c|c|c|c|}
\hline & \multicolumn{3}{|c|}{ EXCHANGE } & \multicolumn{3}{|c|}{ GOVERNMENT } \\
\hline & INFLATION & RATE & INTEREST RATE & TOURIST & EXPENDITURE & INVESTMENT \\
\hline & $\mathrm{X} 1$ & $x 2$ & x3 & X4 & $\times 5$ & $x 6$ \\
\hline \multicolumn{7}{|c|}{ INFLATION } \\
\hline $\mathrm{X} 1$ & 1.000000 & -0.576793 & 0.737785 & -0.228570 & -0.586189 & -0.719297 \\
\hline \multicolumn{7}{|c|}{ EXCHANGE } \\
\hline \multicolumn{7}{|c|}{ RATE } \\
\hline$x 2$ & -0.576793 & 1.000000 & -0.412993 & 0.457029 & 0.911175 & 0.895860 \\
\hline \multicolumn{7}{|c|}{ INTEREST } \\
\hline \multicolumn{7}{|c|}{ RATE } \\
\hline X3 & 0.737785 & -0.412993 & 1.000000 & -0.265493 & -0.463899 & -0.603519 \\
\hline \multicolumn{7}{|c|}{ TOURIST } \\
\hline$X 4$ & -0.228570 & 0.457029 & -0.265493 & 1.000000 & 0.274058 & 0.398317 \\
\hline \multicolumn{7}{|c|}{ GOVERNMENT } \\
\hline \multicolumn{7}{|c|}{ EXPENDITUREX } \\
\hline 5 & -0.586189 & 0.911175 & -0.463899 & 0.274058 & 1.000000 & 0.921201 \\
\hline \multicolumn{7}{|c|}{ INVESTMENT } \\
\hline$x 6$ & -0.719297 & 0.895860 & -0.603519 & 0.398317 & 0.921201 & 1.000000 \\
\hline
\end{tabular}

As can be observed from the results of the multicollinearity test above, there is no correlation value more than 0.90 , indicating that there is no problem with multicollinearity in the study variables.

\subsection{Normality Test}

The normality test is used to determine whether or not the standardized residual value in the regression model is normally distributed. How to do the normality test can be done with a normal probability plot graph analysis approach. The residual value is normally distributed in this approach if the lines (dots) that describe the actual data will follow or move closer to the diagonal line. 

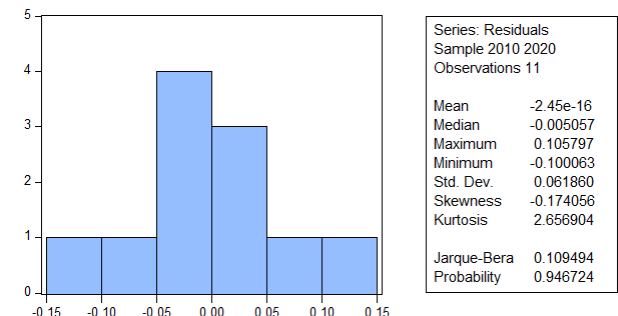

Figure 8. Normality Test Results with Eviews 10.

As can be observed from the test results above, the Jarque probability value is greater than 0.9467 ,

Table 2. Heteroscedasticity Test Results with Eviews 10.

\begin{tabular}{llll} 
F-statistic & 2.013449 & Prob. F(6,4) & 0.2596 \\
Obs $^{\star}$ R-squared & 8.263800 & Prob. Chi-Square(6) & 0.2194 \\
Scaled explained SS & 0.905278 & Prob. Chi-Square(6) & 0.9889 \\
\hline
\end{tabular}

According to the findings of the heteroscedasticity test using the white technique, the prob value is $0.2194>0.05$, indicating that the research model does not exhibit any signs of heteroscedasticity.

\subsection{Autocorrelation Test}

According to [11], autocorrelation might emerge due to the relationship between consecutive observations across time. This issue arises because the residuals are not independent of the preceding indicating that the remaining research data is normally distributed.

\subsection{Heteroscedasticity Test}

A heteroscedasticity test was used to ascertain whether or not there were departures from the conventional assumptions. The regression model must satisfy the condition of being free of heteroscedasticity symptoms. If the prob value is less than 0.05 , heteroscedasticity exists in the research model; if the prob value is more than 0.05 , there is no evidence of heteroscedasticity in the research model.

Table 3. Autocorrelation Test Results with Eviews 10.

Breusch-Godfrey Serial Correlation LM Test:

\begin{tabular}{lllr}
\hline \hline F-statistic & 16.66157 & Prob. F (2,2) & 0.0566 \\
Obs*R-squared & 10.37718 & Prob. Chi-Square (2) & 0.1656 \\
\hline \hline
\end{tabular}

Given that prob $0.1656>0.05$ in the autocorrelation test, it may be inferred that there is no autocorrelation symptom in the research model.

\subsection{Heteroscedasticity Test}

statement. A good regression model is a regression model without autocorrelation. A function test must be done to determine the existence or absence of autocorrelation. The Breusch-Godfrey Test can be used to assess autocorrelation. If the prob value is less than 0.05 , autocorrelation symptoms occur; no autocorrelation symptoms arise if the prob value is more significant than 0.05 . This test is used to determine the presence or absence of serial correlation in the regression model or whether the model used has autocorrelation between the observed variables.

Table 4. Multiple Linear Regression Test Results with Eviews 10.

\begin{tabular}{lllll}
\hline \hline Variable & Coefficient & Std. Error & t-Statistic & Prob.
\end{tabular}




\begin{tabular}{crrrr}
\hline \hline C & 8.610364 & 0.323145 & 26.64550 & 0.0000 \\
INFLATION X1 & -0.046359 & 0.023824 & -1.945923 & 0.1235 \\
EXCHANGE RATE X2 & -0.000287 & $4.23 \mathrm{E}-05$ & -6.792341 & 0.0025 \\
INTEREST RATE X3 & 0.044893 & 0.040358 & 1.112371 & 0.3283 \\
TOURIST X4 & $1.90 \mathrm{E}-07$ & $1.06 \mathrm{E}-08$ & 18.02798 & 0.0001 \\
GOVERNMENT & & & & \\
EXPENDITURE X5 & $-9.88 \mathrm{E}-07$ & $2.22 \mathrm{E}-07$ & -4.446130 & 0.0113 \\
INVESTMENT X6 & $-1.19 \mathrm{E}-06$ & $8.29 \mathrm{E}-07$ & -1.429725 & 0.2260 \\
\hline \hline
\end{tabular}

As illustrated in table 4, the regression equation can be explained as follows.

\section{$\mathrm{Y}=\mathbf{8 . 6 1 0 3 - 0 . 0 4 6 3 X 1 -}$ $0.00028 \times 2+0.0448 \times 3+1.9035 \times 4-9.8751 \times 5-$ $1.1850 \times 6$}

From the regression above, the results of the research can be interpreted as follows:

1) The constant-coefficient value is 8.6103, meaning that if the variables (X1) Inflation, (X2) Exchange rates, (X3) Interest Rates, (X4) Tourist Visits, (X5) Government Expenditures, and (X6) Investment are considered constant, then economic growth will increase amounted to 8,6103 .

2) The value of the inflation coefficient is 0.0463 , and the probability value is 0.1235 > 0.05 , so inflation has no effect on profit growth.

3) The exchange rate coefficient is -0.000287 , and the probability value is $0.0025<0.05$; as a result, it is possible to conclude that the exchange rate has a detrimental influence on economic growth

4) The interest rate coefficient is 0.0448 , and the probability value is $0.3283>0.05$; as a result, interest rates have no discernible influence on economic growth.

5) The coefficient value of foreign tourist visits is 1,900 while the probability value is 0.0001 $<0.05$; as a result, interest rates have no discernible influence on economic growth.

6) The coefficient value of government spending is -9.9880 , and the probability value is $0.015<0.05$; as a result, it has a detrimental influence on the government expenditure variable.

7) The investment coefficient value is -1.1900 , and the probability value is $0.2260>0.05$, So, investment has no influence on economic growth.

\subsection{Partial Test (t-test)}

The influence of an independent variable on the dependent variable is determined using this test. By making use of the hypothesis:

Ho: Not Influential

Ha: Influential

If the value of $t$-value equals $t$-table, Ho is accepted. If $\mathrm{t}$-value $>\mathrm{t}$-table, Ho is refused. Ha: Influential

With the number of $\mathrm{N}=11, \mathrm{~K}=7$ and $\mathrm{DF}=4$, then

1) Inflation has a value of $t$-value $(-9.145)>t$ table (2.132), meaning that inflation partially affects economic growth.

2) The exchange rate has t-value $(-6,792)>t-$ table $(2,132)$, meaning that the exchange rate partially affects profit growth.

3) Interest rates have t-value $(1.1123)<\mathrm{t}$-table (2.132), meaning that interest rates do not affect profit growth.

4) Tourist visits have $t$-value $(18,027)>t$-table $(2,132)$, meaning that tourist visits partially affect profit growth.

5) Government spending has t-value (-4.4461) > $\mathrm{t}$-table $(2,132)$, meaning that government spending partially affects profit growth.

6) Investment has t-value $(8,290)>\mathrm{t}$-table $(2,132)$, meaning that investment partially affects profit growth.

\subsection{Simultaneous Test (F Test)}

The F-test is used to assess the independent variables' combined impact.

\section{Ho: Not Influential}

Ha: Influential

If the value of f-value f-table is allowed, this indicates that Ho is acceptable. If the value of f-value is greater than the value of the f-table, Ho is refused..

$$
\begin{aligned}
& \text { Df } 1=k-1=7-1=6 \\
& \text { Df2=n-k=11-6=5 }
\end{aligned}
$$


Based on table $F$ with a value of df $1=6$ and $\mathrm{df} 2$ $=5$, the value of f-table is 4.95 From the regression results above, it can be seen that the value of $f$-value (221.0907) > f-table value (4.95), so it can be said that the variables X1, X2, X3, X4.X5 and X6 jointly affect the $\mathrm{Y}$ variable.

\section{CONCLUSION}

Based on the results of hypothesis testing, it is concluded that:

1) From the results of the processing carried out using software eviews, inflation affects Indonesia's economic growth from 20102020.

2) The exchange rate influences Indonesia's economic growth in 2010-2020, as seen from the partial or t test.

3) Interest rates do not affect Indonesia's economic growth in 2010-2020.

4) Tourist visits affect Indonesia's economic growth.

5) Government spending influences Indonesia's economic growth.

6) Investment influences Indonesia's economic growth.

\section{AUTHORS' CONTRIBUTIONS}

The results of this study contribute to inflation, exchange rates, interest rates, tourist visits, government spending, investment, significant economic growth to the local economy, especially the increase in local income and new jobs, and local business actors. It certainly benefits directly from the tourism sector. Local communities also benefit when businesses pay workers and spend their growing wealth.

\section{ACKNOWLEDGMENT}

1) Thank you to our parents who always pray for and give encouragement and support in completing this journal

2) Thank you to yourself and your teammates for your cooperation so that we have reached the final

3) Thank you to the supervisor, Mr. Irwan Hermawan, ME who has guided the completion of this journal As well as comrades in arms who pray for and give encouragement in the process of this journal.

\section{REFERENCES}

[1] N. Comerio and F. Strozzi, "Tourism and its economic impact: A literature review using bibliometric tools," Tour. Econ., vol. 25, no. 1, pp. 109-131, 2019, doi: $10.1177 / 1354816618793762$.

[2] J. E. Rodiek, "Where do we go from here?," Landsc. Urban Plan., vol. 58, no. 1, pp. 1-4, 2002, doi: 10.1016/S0169-2046(01)00241-9.

[3] N. Danila and V. Mccarthy, "Volume 26 ( 2 ) Audit Fee Premium for Industry Specialization: A Developed Country Perspective Muhammad Shahin Miah 1-11 Socio-Demographics," vol. 26, no. January, 2019.

[4] T. M. Obamuyi and S. Olorunfemi, "Financial reforms, interest rate behaviour and economic growth in Nigeria," J. Appl. Financ. Bank., vol. 1, no. 4, pp. 1792-6599, 2011.

[5] A. Shahzad and A. K. Al-Swidi, "Effect of macroeconomic variables on the FDI inflows: The moderating role of political stability: An evidence from Pakistan," Asian Soc. Sci., vol. 9, no. 9, pp. 270-279, 2013, doi: 10.5539/ass.v9n9p270.

[6] Mankiw, PRINCIPLES OF ECONOMICS, 3rd ed. Jakarta: Salemba empat, 2006.

[7] A. Abdallah, "Night-Time Economy in Beirut : Modernization and Re-Branding As a Recovery Mechanism for Tourism Development in Lebanon .," no. March 2015, pp. 7-23, 2015.

[8] T. Turan, H. Yanikkaya, and H. A. Özer, "Economic Growth Effects of Public and Private Investment: Evidence from Dynamic Panel Estimation for Developed and Developing Countries," Prague Econ. Pap., vol. 30, no. 5, pp. 613-631, 2021, doi: 10.18267/j.pep.781.

[9] H. H. Lean, S. H. Chong, and C. W. Hooy, "Tourism and economic growth: Comparing Malaysia and Singapore," Int. J. Econ. Manag., vol. 8, no. 1, pp. 139-157, 2014.

[10] Sugiyono, METODE PENELITIAN. Bandung, 2016.

[11] Ghozali, Aplikasi Analisis Multivariate, 9th ed. Semarang: Universitas Diponegoro, 2018.

[12] V. W. Sujarweni, Kupas Tuntas Penelitian Akuntansi Dengan SPSS, 1st ed. Yogyakarta, 2016. 